\title{
Prior to the Financial Security through Control over the Use of Public Funds, Assessment Methodology and Practical Experience in Ukraine
}

\author{
Oleksiy Esmanov \\ $\mathrm{PhD}$, Head of the Department, State Auditor Service, Ukraine
}

\section{Peter Dunne}

Managing Director, Spitalfields Co Ltd, London, England

\begin{abstract}
The social and political instability in the world actualizes the task of protecting national financial interests from external and internal destabilizing factors, ensuring financial security. Traditionally, one of the significant threats to financial security is the increase in the number and volume of offenses in the use of state financial resources, inadequate performance of official duties by responsible officials of executive authorities and local selfgovernment, managers and recipients of budget funds, economic entities of the state and communal sectors of the economy . Therefore, the organization effectively control the movement of funds accumulated in the budgets of various levels and extra-budgetary funds, which is the task of the state financial control should be considered as one of the most important elements of the system to ensure financial security.
\end{abstract}

Keywords: control, finance, financial security, state financial control, system of state financial control.

JEL Classification: G38.

(C) The Authors, 2017. This article is published with open access at ARMG Publishing.

\section{Introduction}

At the present stage of development particular relevance to the issues of financial security, which is the degree of protection of the financial interests of the state, the state of financial, monetary, budgetary, fiscal, monetary, banking, investment, customs tariff, settlement and stock systems, which are characterized by a balance, resistance to internal and external negative influences, the ability of the state to effectively formulate and rationally use financial resources sufficient to meet its needs, by fulfilling commitments and ensuring social and economic development. The state can not function and develop without a well-organized system of control over the production, distribution and redistribution of social product and other areas of public life in the country. Monitoring is an integral part of the superstructure of society, which is undergoing major changes in the development of its political system, government and economic management, legislative and executive. Of particular importance is the state control under conditions of economic entities with different forms of ownership.

Financial control is a complex and purposeful financial and legal activity of the financial control bodies or their subdivisions or representatives, as well as persons authorized to exercise control based on the provisions of the acts of the current legislation. This type of control involves checks of commercial and financial transactions on their validity, legality, appropriateness and efficiency.

State financial control is the type of financial control exercised by the relevant state financial control. It consists in establishing the actual state of affairs in relation to compliance with the requirements of the current legislation on the controlled object aimed at ensuring legality, financial discipline and rationality in the course of the formation, distribution, possession, use and alienation of assets owned by the state, as well as the use of funds that remain in the subject of financial legal relations.

Distributed worldwide methods of financial security spread around the world have a number of disadvantages, which lead to significant distortions in the evaluation results.

the necessity of expert setting and constant adjustment of weight coefficients, optimal and threshold values for each of the indicators of financial security, and also the existence of a complex procedure for their normalization to obtain an integral assessment; 
a significant number of financial security indicators do not have a strong correlation with the indicators of socioeconomic development of the country and economic growth, while it is their increase that is the ultimate goal of ensuring financial security;

for individual indicators of financial security, the information base for calculation is the expert data of state organizations and non-government rating agencies, the adequacy of which is often questionable;

- calculations are made only by retrospective data, leaving out the possibility of new financial security threats;

- separate indicators by their nature and mechanism of calculation are duplicated or mutually interconnected,

which leads to a double count of the influence of individual factors;

- the state of financial discipline in the implementation of operations with state funds and property by executive and local self-government bodies, local communities, administrators and recipients of budget funds, economic entities of the state and communal sectors of the economy remains unmet.

The fundamental principles of the study of the role of the state control function in ensuring the country's financial security are laid down in the scientific work of such scholars: W. Allen, L. Abalkina, S. Agaptsova, V. Burtseva, E. Buchwald, Z. Bodie, G. Wood, R. Duflot, V. Zhukova, D. Lambert, R. Nolan, T. Manaseryan, R. Merton, V. Burtsev, Ju. Voronin, A. Kozyrin, O. Gorbunova, S. Shohin, L. Voronina, E. Pevtsova, N. Cernogor, D. Olifer, N. Goranin, A. Kaceniauskas, A. Cenys, M. Aoki, D. Batten, H. Neugart, E. Fehr, A. Falk and others.

\section{Methods and findings}

According to the tasks authors used the following methods: statistical analysis grouping (with justification field of public financial control system to ensure financial security), correlation and regression analysis and principal component analysis method (at assessing the level of financial security).

When addressing the integrated assessment of financial security, we consider specific indicators, what can influence its level. On this basis, we believe that the first step towards establishing a list of indicators should be to determine the relevant indicators, rather than the formation of subindices.

In order to develop a list of financial security level indicators, we consider that it is necessary to use the bases of statistical analysis, proving the correctness of their reflections with appropriate calculations and indicators. At the same time, the use of correlation and regression analysis must select a base reference rate, the dynamics of which would be most revealing and most commonly described condition of economic prosperity in the country. Indicators are divided into two groups: to take into account not only current but also potential threats to financial security indicators: direct action (with a high level of correlation with the level of GDP) and promising action (with a high level of correlation with the rate of GDP growth). We should pay attention to one important aspect of the current guidelines for determining the level of financial bezpeky- score only present condition. The level of security is determined by the results of historical analysis of indicators and creates an idea only of the current state of financial security, without considering future threats.

Given the fact that GDP is an absolute macroeconomic indicator, which characterizes the value stream value added during the period, we believe that it is best suited for the analysis of the current state of financial security. At the same time, economic growth is defined as a dynamic relative indicator and fully in line with the principles of the analysis of dynamics. Thus, indicators whose relationship with GDP is high (the coefficient of correlation exceeds 0.75 ) is attributed to the indicators of direct action, and with the rate of GDP growth - to indicators of promising action.

Solving the problem of selection criteria and grouping of indicators should take into account the direction of the index to the target criterion to ensure financial security. Among the indicators of direct action, we propose to allocate stimulants (positive value correlation coefficient) and stimulators (negative value correlation coefficient). At this stage determine the factors within the direct indicators which have a stimulatory or destructive effect on GDP. Factors are selected from the list of actions that are relevant in nature. To determine factors such as financial security for Ukraine, we have formed a list of the most important indicators, based on the analysis of reporting the most structurally important government agencies and organizations.

Indicators of promising action are proposed to be divided into catalysts (positive value correlation coefficient) and inhibitors (negative value correlation coefficient. At this stage, we estimate that the indicators have the greatest impact on safety and create opportunities for its increase or, conversely, are capable of increasing negative impact on the level of economic growth. The allocated stimulants with a correlation coefficient of 
more than 0.75 are presented in Table 1 . The list of decomposers with the corresponding values of the correlation coefficients is given in Table 2.

Table 2. Relevant de-stimulators for determining the level of financial security of Ukraine (dynamics for 2007-2013 and correlation coefficient)

\begin{tabular}{|c|c|c|c|c|c|c|c|c|}
\hline \multirow[t]{2}{*}{ Indicators } & \multicolumn{7}{|c|}{ Years } & \multirow{2}{*}{$\begin{array}{ll}\text { Coefficient } & \text { of } \\
\text { correlation } & \text { to } \\
\text { GDP } & \end{array}$} \\
\hline & 2007 & 2008 & 2009 & 2010 & 2011 & 2012 & 2013 & \\
\hline 1 & 2 & 3 & 4 & 5 & 6 & 7 & 8 & 9 \\
\hline $\begin{array}{l}\text { Gross international reserves of } \\
\text { Ukraine, months of import }\end{array}$ & 5.41 & 3.78 & 5.66 & 5.67 & 3.85 & 2.81 & 2.12 & -0.81 \\
\hline $\begin{array}{l}\text { Relation of the amount of re- } \\
\text { serves to the Bank, } \%\end{array}$ & 40.68 & 30.97 & 25.63 & 29.50 & 25.20 & 18.15 & 14.36 & -0.91 \\
\hline $\begin{array}{l}\text { Deficit / surplus of budget and } \\
\text { extrabudgetary funds of the } \\
\text { state-owned sector, percent- } \\
\text { age of GDP }\end{array}$ & 2.76 & 2.35 & 2.33 & 0.83 & 1.24 & 0.80 & 0.26 & -0.91 \\
\hline Consumer price index, $\%$ & 116.6 & 122.3 & 112.3 & 109.1 & 104.6 & 99.80 & 100.5 & -0.88 \\
\hline $\begin{array}{l}\text { Inflation rate (as of December } \\
\text { of the previous year), } \%\end{array}$ & 116.6 & 122.3 & 112.3 & 109.1 & 104.6 & 99.80 & 100.5 & -0.88 \\
\hline $\begin{array}{l}\text { The ratio of bank loans and de- } \\
\text { posits in foreign currency, per- } \\
\text { centages }\end{array}$ & 232.7 & 274.7 & 227.2 & 190.2 & 153 & 118.8 & 124.1 & -0.90 \\
\hline $\begin{array}{l}\text { The share of loans in foreign } \\
\text { currency in the total amount of } \\
\text { loans granted, percentages }\end{array}$ & 49.90 & 59.10 & 51.40 & 44.00 & 41.70 & 34.90 & 32.10 & -0.85 \\
\hline $\begin{array}{l}\text { Share of consumer loans in the } \\
\text { general structure of loans, } \%\end{array}$ & 23.69 & 23.49 & 18.34 & 16.29 & 15.29 & 15.33 & 15.06 & -0.86 \\
\hline $\begin{array}{l}\text { Share of consumer loans } \\
\text { granted to households in the } \\
\text { general structure of loans } \\
\text { granted to residents }\end{array}$ & 26.94 & 25.34 & 18.95 & 16.78 & 15.71 & 15.34 & 15.04 & -0.87 \\
\hline
\end{tabular}

Source: own calculations.

Definition of indicators of promising steps took place on the same approach, but as a criterion for calculating the correlation coefficient chosen economic growth (GDP growth). The results are presented in Table 3.

Table 3. Relevant indicators of promising action for determining the level of financial security of Ukraine (dynamics for 2007-2013 and correlation coefficient)

\begin{tabular}{|c|c|c|c|c|c|c|c|c|}
\hline \multirow[t]{2}{*}{ Indexes } & \multicolumn{7}{|c|}{ Years } & \multirow{2}{*}{$\begin{array}{l}\text { Corr. coef. } \\
\text { to economic } \\
\text { growth rates }\end{array}$} \\
\hline & 2007 & 2008 & 2009 & 2010 & 2011 & 2012 & 2013 & \\
\hline 1 & 2 & 3 & 4 & 5 & 6 & 7 & 8 & 9 \\
\hline \multicolumn{9}{|c|}{ Catalysts } \\
\hline Profitability of banks' assets, $\%$ & 1.5 & 1.03 & -4.38 & -1.45 & -0.76 & 0.45 & 0.12 & 0.83 \\
\hline Return on capital of banks, $\%$ & 12.67 & 8.51 & -32.52 & -10.19 & -5.27 & 3.03 & 0.81 & 0.83 \\
\hline $\begin{array}{l}\text { Growth of real disposable income of } \\
\text { physical persons, } \%\end{array}$ & 114.8 & 107.6 & 90 & 117.1 & 108 & 113.9 & 105.3 & 0.87 \\
\hline $\begin{array}{l}\text { Results of activity (profit) of enter- } \\
\text { prises, UAH billions. }\end{array}$ & 6.3 & 7.3 & -38.45 & -13 & -7.7 & 4.9 & 1.4 & 0.81 \\
\hline Return on assets of enterprises, $\%$ & 1.5 & 1.03 & -4.38 & -1.45 & -0.76 & 0.45 & 0.12 & 0.83 \\
\hline \multicolumn{9}{|c|}{ Inhibitors } \\
\hline $\begin{array}{l}\text { The ratio of long-term (over } 1 \text { year) } \\
\text { loans and deposits, times }\end{array}$ & 2.27 & 3.22 & 6.17 & 3.75 & 3.10 & 2.37 & 1.76 & -0.81 \\
\hline Deposit rates, $\%$ & 7.20 & 8.30 & 11.80 & 9.40 & 7.30 & 11.30 & 9.50 & -0.81 \\
\hline Rates on loans, $\%$ & 13.50 & 16.00 & 18.30 & 14.60 & 14.30 & 15.50 & 14.40 & -0.94 \\
\hline $\begin{array}{l}\text { Share of public debt securities cov- } \\
\text { erage, } \%\end{array}$ & 20.22 & 52.62 & 81.81 & 49.84 & 31.13 & 22.54 & 28.70 & -0.80 \\
\hline
\end{tabular}

Source: own calculations.

The next step in improving teaching principles determining the level of financial security is to normalize the relevant indicators. Given the fact that these units of measurement parameters are different, to assess the level 
of financial security should translate them into binary system ( 0 or 1$)$, depending on the impact the dynamics of change in the level of financial security, based on the correlation coefficient. In other words, the indicators received an estimate of 1 or 0 , depending on whether they grew or decreased, and how their change affected the state of financial security. The value of weighting coefficients of indicators of financial security determined empirically based statistical density relationships. The corresponding weighting factors are given in Table 4 (see in Appendix).

After receiving all the necessary data to assess the financial security of Ukraine by copyright approach skorystuyemosya the formula for its determination: $S_{F S}=\sum_{k=1}^{n} p_{k j} \cdot h_{k}$,

where $S_{F S}-$ level of financial security;

$p_{k j}$ - normalized values of $k$ indicator of financial security;

$h_{k}$ - the specific weight of k-th indicator of financial security.

The proposed method allows us to simplify the definition of financial security without reducing the quality of the relevant calculations. Comparing the dynamics of the key economic indicators and the level of financial security in Ukraine, as defined by our author's approach indicates coincidence trends. The dynamics of the main economic indicators and the level of financial security is presented in Fig. 1-3.

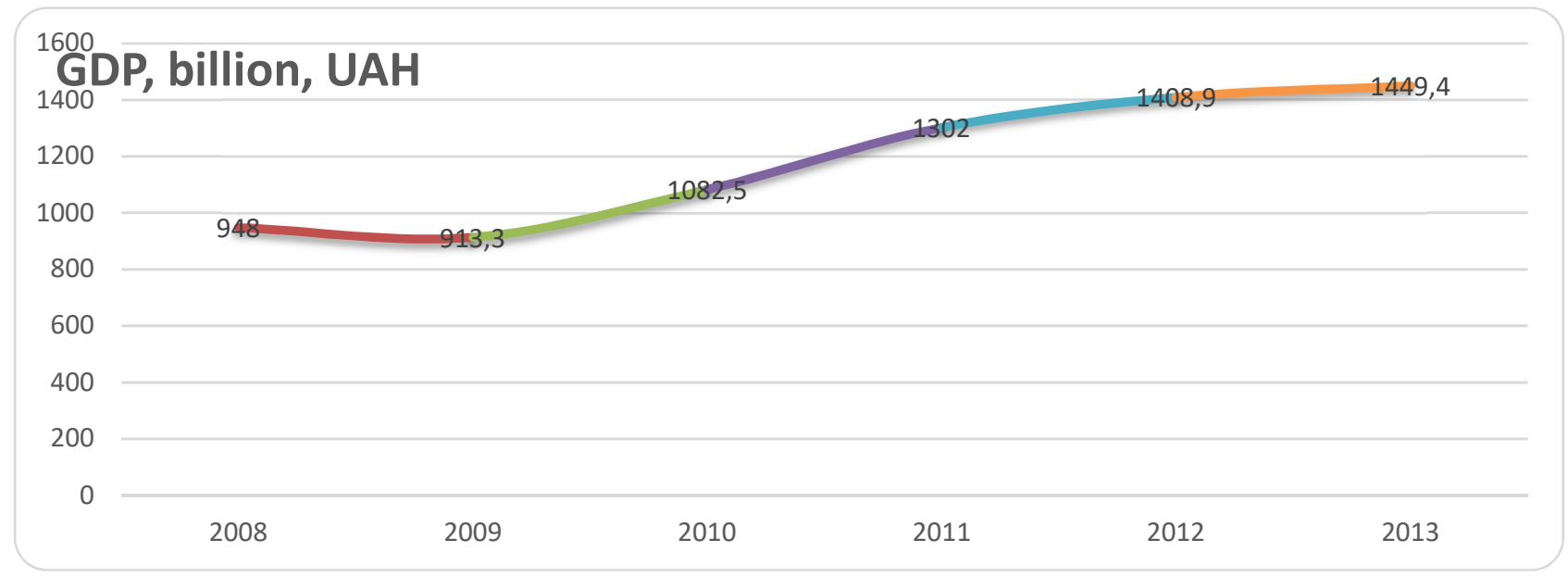

Figure 1. Dynamics of GDP of Ukraine during 2008-2013

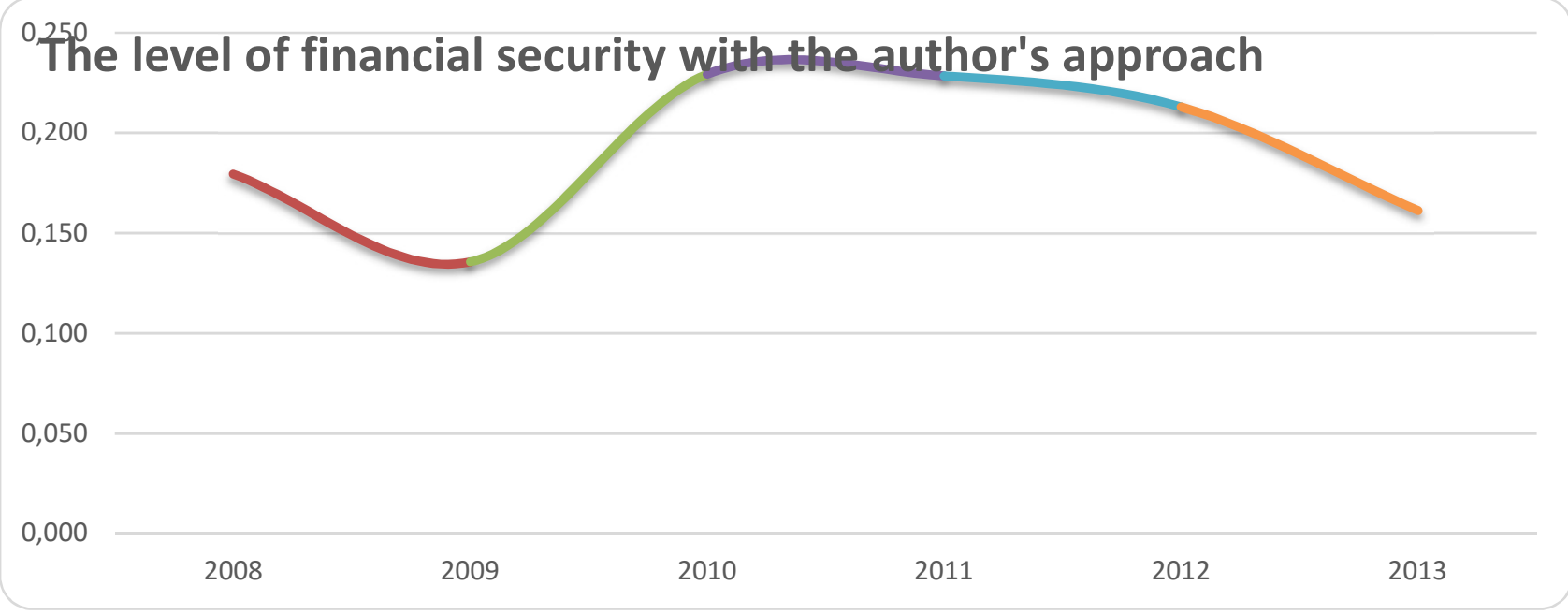

Figure 2. Dynamics of economic growth in Ukraine during 2008-2013 


\section{Economic growth, \%}

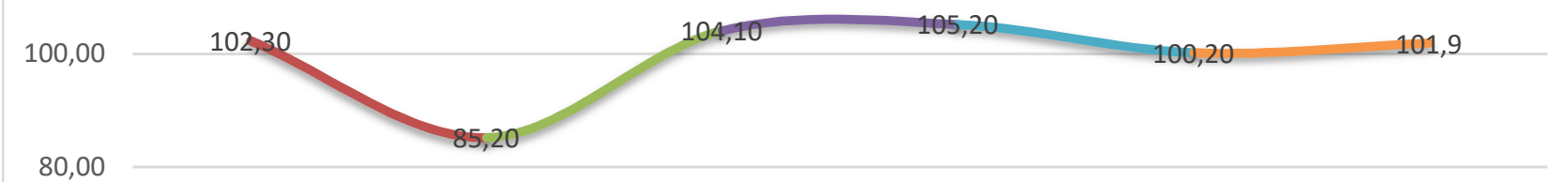

80,00

60,00

40,00

20,00

0,00
2008
2009
2010
2011
2012
2013

Figure 3. Dynamics of financial security in Ukraine, designed by the author's approach during 2008-2013

In general, the scientific and methodological principles for determining the level of financial security in the light of author's proposals are presented in Figure 4.

Stage 1: Formation of the initial set of financial safety indicators (137 indicators) and the information data set for 2007-2013.

Stage 2: Formalization of the correlation links of financial security indicators with the level of GDP and the rate of GDP growth.

Stage 3: Formation of the final set of financial security indicators (only those whose correlation coefficient exceeds 0.75 )

Stage 4: Normalization of indicators of financial security by bringing to values in the range $[0,1]$ taking into account the direction of the impact on financial security

Stage 5: The calculation of the level of financial security as the sum of the normalized values of all its indicators, taking into account their specific gravity

$$
S_{F S}=\sum_{k=1}^{n} p_{k j} \cdot h_{k}
$$

\section{Figure 4. Scientific approach to definition of financial security}

The scientific approach proposed by the authors creates an opportunity to determine the level of financial security with a high degree of reliability and has several advantages compared with the existing, which distinguishes it qualitatively. This approach differs from existing ones as follows:

1) for the strict coordination of the mechanism for assessing financial security in order to ensure that financial safety indicators include only those indicators whose correlation with macroeconomic characteristics of the country's socio-economic development and economic growth is dense, which allowed for a clear compliance with the mechanism for calculating the purpose providing financial security;

2) to take into account not only current but also potential threats to financial security, the indicators are divided into two groups: direct action (with a high level of correlation with the level of GDP) and promising action (with a high level of correlation with the rate of GDP growth ); 
3) to avoid duplication in calculations there is no clear fixing of indicators on the structural components of financial security;

4) to take into account the multidirectional effect of indicators on the level of financial security (some increase leads to an increase in the level of financial security, while others to decrease), they are divided into stimulators, stimulants, catalysts and inhibitors.

5 ) in order to take into account the influence of the effectiveness of control over the use of public funds on the level of financial security, its indicators include an aggregate indicator of violations of financial discipline in the implementation of transactions with public funds and property.

\section{Conclusions}

In order to increase the level of financial security, it is important to increase the level of financial discipline in the implementation of transactions with public funds and property, while minimizing the threats to national financial interests, ensuring the legality, completeness and purpose of spending public funds. The methodological recommendations for assessing the level of financial security developed in different countries of the world have significant methodological disadvantages, which lead to significant distortion of the evaluation results. In particular, in assessing each of the components of financial security, some aspects of the use of public financial resources and property, the control over which implementation is essential in the context of providing financial security. It is recommended to calculate the level of financial security taking into account the state of financial discipline in the implementation of transactions with public funds and property, as well as correlation with the level of GDP and the rate of its growth. The grouping of financial security indicators is recommended not for the structural components of financial security, but for the time horizon of the emergence of financial security threats and the direction of impact on the level of economic development.

\section{References}

1. Allen W. and Wood G. (2006). Defining and achieving financial stability. Journal of Financial Stability, 2(2), 52-72.

2. Economic security [Online]. Retrieved from http://en.wikipedia.org/wiki/Economic security\#cite note-1.

3. Lambert D. (1990). La defence de l'economie: la conjugaison des efforts de l'Etat, de l'enterprise et d'individu, Strategigue, 2, 83-98.

4. Nolan R. L. (1973). Mananaging the Computer Resourse: A Stage Hypothesis. Communications of ACM, 16 (7), $399-405$.

5. Baranovs'kyy, O. I. (2004). Finansova bezpeka $v$ Ukrayini (metodolohiya otsinky ta mekhanizmy zabezpechennya) [The financial security in Ukraine (methodology of estimation and mechanisms of ensuring)], Vyd-vo Kyiv. nats. torh.-ekon. un-t, Kyiv, Ukraine.

6. Basantsov, I. V. (2008). Development of state financial control in a market economy of Ukraine. Ph.D. Thesis, Money, finance and credit, National University of STS of Ukraine, Irpin, Ukraine.

7. Belukha, N. T. (1996). Teorija finansovo-hozjajstvennogo kontrolja i audita [The theory of financial and economic control and audit], PP «Vlad y Vlada», Kyiv, Ukraine.

8. Burtsev, V. B. (2002). Organizacija sistemy gosudarstvennogo finansovogo kontrolja v Rossijskoj Federacii: teorija i praktika [Organization of the system of state financial control in the Russian Federation: Theory and Practice], Dashkov i Co., Moscow, Russia.

9. Voronin, Ju. M. (2005). Gosudarstvennyj finansovyj kontrol': voprosy teorii i praktiki [State Financial Control: Theory and Practice], Knizhnyj Dom, Minsk, Belarus.

10. Kozyrin, A. N. and Gorbunova, O. N. (1996). Finansovyj kontrol' [Financial control], Jurist', Moscow, Russia.

11. Napadovs'ka, L.V. (2000). Vnutrishn'ohospodars'kyj kontrol' v rynkovij ekonomitsi; Monohrafiia [Internal control in a market economy: Monograph], Nauka i osvita, Dnipropetrovs'k, Ukraine.

12. Pavliuk, K.V. (2006). Biudzhet i biudzhetnyj protses v umovakh tranzytyvnoi ekonomiky Ukrainy: monohrafiia [The budget and the budget process in conditions transitive economy of Ukraine: Monograph], NDFI, Kyiv, Ukraine.

13. Telepneva, A.V. (2008). Financial control as a function of the state. Vestnik Sankt-Peterburgskogo universiteta MVD Rossii, 2, 58.

14. Shohin, S.O. and Voronina, L.I. (1997). Bjudzhetno-finansovyj kontrol' i audit. Teorija i praktika primenenija v Rossii [Budget and financial control and audit. Theory and Practice in Russia], Finansy i statistika, Moscow, Russia.

15. Elena Pevtsova, Nicolai Cernogor (2015). Financial control mechanism to ensure the effectiveness of legal regulation of the education system: theoretical and international legal aspects. Journal of Research on Trade, Management and Economic Development, 2(2), 47-56.

16. Dmitrij Olifer, Nikolaj Goranin, Arnas Kaceniauskas \& Antanas Cenys (2017). Controls-based approach for evaluation of information security standards implementation costs. Technological and Economic Development of Economy, 23(1), 196-219. Doi: http://dx.doi.org/10.3846/20294913.2017.1280558. 
17. Batten, David F. (2000). Discovering artificial economics: how agents learn and economies evolve. Westview Press, Boulder, $304 \mathrm{p}$.

18. Dawid, H, Neugart, M. (2011). Agent-based models for economic policy design. Eastern Economic Journal, 37, 44-50. 19. Fehr, E., Falk, A. (2002). Reciprocal fairness, cooperation and limits to competition, in E. Fullbrook (ed) Intersubjectivity in economics: agents and structures. Routledge, New York. pp. 28-55.

\section{Appendix}

Table 1. Relevant stimulants for determining the level of financial security of Ukraine (dynamics for 20072013 and correlation coefficient)

\begin{tabular}{|c|c|c|c|c|c|c|c|c|}
\hline \multirow[t]{2}{*}{ Indexes } & \multicolumn{7}{|c|}{ Years } & \multirow{2}{*}{$\begin{array}{ll}\text { Coefficient } & \text { of } \\
\text { correlation } & \text { to } \\
\text { GDP } & \end{array}$} \\
\hline & 2007 & 2008 & 2009 & 2010 & 2011 & 2012 & 2013 & \\
\hline 1 & 2 & 3 & 4 & 5 & 6 & 7 & 8 & 9 \\
\hline $\begin{array}{l}\text { Assets of banks, billion } \\
\text { UAH }\end{array}$ & 599.40 & 926.10 & 880.30 & 942.10 & 1054.30 & 1127.20 & 1278.10 & 0.95 \\
\hline $\begin{array}{l}\text { Gross External Debt, Bil- } \\
\text { lion Dollars USA }\end{array}$ & 79.90 & 101.70 & 103.40 & 117.30 & 126.20 & 135.00 & 142.00 & 0.99 \\
\hline $\begin{array}{l}\text { The expenditures of the } \\
\text { state budget, billion UAH }\end{array}$ & 174.20 & 241.40 & 242.40 & 303.60 & 333.50 & 395.70 & 403.40 & 0.99 \\
\hline $\begin{array}{l}\text { Consolidated budget } \\
\text { expenditures, bln. }\end{array}$ & 226.00 & 309.20 & 307.40 & 377.80 & 416.85 & 492.50 & 505.80 & 0.99 \\
\hline $\begin{array}{l}\text { The ratio of domestic debt } \\
\text { to GDP, } \%\end{array}$ & 2.47 & 4.71 & 9.97 & 13.09 & 12.40 & 13.51 & 14.33 & 0.86 \\
\hline Money base, billion UAH & 141.90 & 186.70 & 194.90 & 225.70 & 239.90 & 255.30 & 307.10 & 0.95 \\
\hline $\begin{array}{l}\text { Deposits in foreign cur- } \\
\text { rency, UAH billions. }\end{array}$ & 90.10 & 157.90 & 154.30 & 174.20 & 208.40 & 248.40 & 248.20 & 0.98 \\
\hline $\begin{array}{l}\text { Deposits on the interbank } \\
\text { market, UAH billions. }\end{array}$ & 712.30 & 1180.90 & 1023.75 & 1228.10 & 1284.80 & 1571.50 & 1601.30 & 0.96 \\
\hline $\begin{array}{l}\text { Deposits of residents in } \\
\text { foreign currency, UAH } \\
\text { billions. }\end{array}$ & 91.60 & 157.90 & 161.90 & 177.30 & 211.30 & 252.10 & 248.20 & 0.98 \\
\hline Deposits, billion UAH & 283.90 & 359.70 & 334.90 & 416.60 & 491.70 & 572.30 & 669.90 & 0.97 \\
\hline State debt to GDP, $\%$ & 9.90 & 13.80 & 24.90 & 29.90 & 27.40 & 28.30 & 33.12 & 0.82 \\
\hline $\begin{array}{l}\text { Long-term loans, billion } \\
\text { UAH }\end{array}$ & 118.70 & 171.20 & 191.50 & 221.60 & 260.30 & 260.10 & 277.50 & 0.97 \\
\hline $\begin{array}{l}\text { Revenues of the state } \\
\text { budget, billion UAH }\end{array}$ & 165.90 & 231.70 & 209.70 & 240.60 & 314.60 & 346.00 & 339.20 & 0.99 \\
\hline $\begin{array}{l}\text { Consolidated budget } \\
\text { revenues, bln. }\end{array}$ & 219.90 & 297.80 & 273.00 & 314.50 & 398.00 & 445.50 & 442.80 & 0.99 \\
\hline $\begin{array}{l}\text { Income of the population, } \\
\text { billion UAH }\end{array}$ & 623.30 & 845.60 & 894.30 & 1101.20 & 1266.80 & 1457.90 & 1529.40 & 0.99 \\
\hline $\begin{array}{l}\text { Total volume of trades for } \\
\text { the period, UAH billions. }\end{array}$ & 31.50 & 45.60 & 15.80 & 61.40 & 89.10 & 89.70 & 90.30 & 0.92 \\
\hline $\begin{array}{l}\text { Capital of banks, billion } \\
\text { UAH }\end{array}$ & 69.60 & 119.30 & 115.20 & 137.70 & 155.50 & 169.30 & 192.60 & 0.98 \\
\hline $\begin{array}{l}\text { The number of registered } \\
\text { unemployed, million peo- } \\
\text { ple }\end{array}$ & 0.60 & 0.85 & 0.50 & 1.70 & 1.60 & 1.60 & 1.50 & 0.82 \\
\hline $\begin{array}{l}\text { Loans granted, UAH } \\
\text { billions }\end{array}$ & 485.40 & 792.20 & 747.35 & 755.00 & 825.30 & 815.30 & 911.40 & 0.83 \\
\hline $\begin{array}{l}\text { Loans to business entities, } \\
\text { UAH billions. }\end{array}$ & 276.20 & 472.60 & 475.00 & 508.30 & 580.90 & 609.20 & 698.80 & 0.95 \\
\hline Loans, UAH billions & 485.40 & 792.20 & 747.35 & 755.00 & 825.30 & 815.30 & 911.40 & 0.83 \\
\hline M0 billion UAH & 87.58 & 154.70 & 157.00 & 183.00 & 192.60 & 203.20 & 237.80 & 0.94 \\
\hline
\end{tabular}


Table 1 (cont.). Relevant stimulants for determining the level of financial security of Ukraine (dynamics for 2007-2013 and correlation coefficient)

\begin{tabular}{|c|c|c|c|c|c|c|c|c|}
\hline \multirow[t]{2}{*}{ Indexes } & \multicolumn{7}{|c|}{ Years } & \multirow{2}{*}{$\begin{array}{ll}\text { Coefficient } & \text { of } \\
\text { correlation } & \text { to } \\
\text { GDP } & \end{array}$} \\
\hline & 2007 & 2008 & 2009 & 2010 & 2011 & 2012 & 2013 & \\
\hline 1 & 2 & 3 & 4 & 5 & 6 & 7 & 8 & 9 \\
\hline M1 billion UAH & 181.66 & 225.10 & 233.70 & 289.90 & 311.00 & 323.20 & 383.80 & 0.96 \\
\hline M2 billion UAH & 392.30 & 512.50 & 484.80 & 596.80 & 681.80 & 771.10 & 906.20 & 0.97 \\
\hline M3 billion UAH & 396.15 & 515.70 & 487.30 & 597.90 & 685.50 & 773.20 & 909.00 & 0.97 \\
\hline State debt service, bln., UAH & 3.30 & 3.80 & 9.00 & 15.50 & 23.10 & 24.20 & 26.70 & 0.96 \\
\hline $\begin{array}{l}\text { Volume of transactions } \\
\text { with government securi- } \\
\text { ties, billions UAH. }\end{array}$ & 54.30 & 85.30 & 73.00 & 275.00 & 411.75 & 638.60 & 256.70 & 0.81 \\
\hline $\begin{array}{l}\text { Volume of trades on the se- } \\
\text { curities market, bln. UAH. }\end{array}$ & 754.31 & 883.39 & 1067.26 & 1537.79 & 2171.10 & 2530.87 & 1676.97 & 0.88 \\
\hline $\begin{array}{l}\text { Volumes of assets of } 5 \\
\text { largest banks, bln. UAH. }\end{array}$ & 198.20 & 308.80 & 303.45 & 346.80 & 385.70 & 435.35 & 511.20 & 0.97 \\
\hline $\begin{array}{l}\text { Share of long-term loans } \\
\text { in the total volume of } \\
\text { loans granted by commer- } \\
\text { cial banks, } \%\end{array}$ & 26.72 & 31.80 & 31.20 & 37.00 & 42.00 & 48.35 & 53.42 & 0.98 \\
\hline $\begin{array}{l}\text { Regulatory capital, billion } \\
\text { UAH }\end{array}$ & 72.30 & 123.10 & 135.80 & 160.90 & 178.40 & 178.90 & 205.00 & 0.95 \\
\hline $\begin{array}{l}\text { The level of foreign debt } \\
\text { per one person, USD USA }\end{array}$ & 1718.28 & 2199.13 & 2247.83 & 2555.56 & 2761.49 & 2960.53 & 3123.30 & 0.99 \\
\hline $\begin{array}{l}\text { The average weighted in- } \\
\text { terest rate on loans in rela- } \\
\text { tion to the consumer price } \\
\text { index, } \%\end{array}$ & -2.66 & -5.15 & 5.34 & 5.04 & 9.27 & 16.23 & 19.54 & 0.90 \\
\hline $\begin{array}{l}\text { The average weighted in- } \\
\text { terest rate on loans granted } \\
\text { by deposit-taking corpora- } \\
\text { tions (except the National } \\
\text { Bank) in the national cur- } \\
\text { rency, in relation to the } \\
\text { consumer price index, per- } \\
\text { centage points }\end{array}$ & -3.10 & -6.30 & 6.00 & 5.50 & 9.70 & 15.70 & 13.90 & 0.87 \\
\hline $\begin{array}{l}\text { The average interest rate } \\
\text { on commercial banks' } \\
\text { loans in relation to infla- } \\
\text { tion, } \%\end{array}$ & -2.66 & -5.15 & 5.34 & 5.04 & 9.27 & 16.23 & 19.54 & 0.90 \\
\hline $\begin{array}{l}\text { Average nominal wage, } \\
\text { UAH }\end{array}$ & 1351.00 & 1806.00 & 1906.00 & 2239.00 & 2633.00 & 3026.00 & 3265.00 & 0.99 \\
\hline $\begin{array}{l}\text { The ratio of liquid assets } \\
\text { to short-term liabilities, } \\
\text { percentages }\end{array}$ & 39.93 & 32.99 & 35.88 & 91.19 & 94.73 & 90.28 & 89.11 & 0.84 \\
\hline $\begin{array}{l}\text { The share of foreign bank } \\
\text { capital in the total amount } \\
\text { of bank capital, } \%\end{array}$ & 17.00 & 17.00 & 18.00 & 20.00 & 22.00 & 22.00 & 21.50 & 0.94 \\
\hline $\begin{array}{l}\text { Share of insurance premi- } \\
\text { ums of the three largest in- } \\
\text { surance companies in the } \\
\text { total amount of insurance } \\
\text { premium receipts (except } \\
\text { life insurance), percent }\end{array}$ & 20.70 & 25.10 & 29.90 & 31.90 & 32.30 & 35.60 & 34.78 & 0.91 \\
\hline $\begin{array}{l}\text { The share of the total au- } \\
\text { thorized capital of insur- } \\
\text { ance companies belonging } \\
\text { to non-residents in their } \\
\text { total volume, } \%\end{array}$ & 20.70 & 25.10 & 29.90 & 31.90 & 32.30 & 35.60 & 34.78 & 0.91 \\
\hline
\end{tabular}

Source: own calculations. 
Table 4. The weights for calculating the level of financial security in Ukraine

\begin{tabular}{|c|c|}
\hline Indicators & Value of weight coefficients \\
\hline 1 & 2 \\
\hline \multicolumn{2}{|c|}{ Stimulants } \\
\hline Assets of banks, billion UAH & 0.01792 \\
\hline Gross External Debt, Billion Dollars USA & 0.01858 \\
\hline The expenditures of the state budget, billion UAH & 0.01866 \\
\hline Consolidated budget expenditures, bln. & 0.01867 \\
\hline The ratio of domestic debt to GDP, $\%$ & 0.01626 \\
\hline Money base, billion UAH & 0.01799 \\
\hline Deposits in foreign currency, UAH billions. & 0.01856 \\
\hline Deposits on the interbank market, UAH billions. & 0.01802 \\
\hline Deposits of residents in foreign currency, UAH billions. & 0.01847 \\
\hline Deposits, billion UAH & 0.01824 \\
\hline State debt to GDP, $\%$ & 0.01551 \\
\hline Long-term loans, billion UAH & 0.0183 \\
\hline Revenues of the state budget, billion UAH & 0.01869 \\
\hline Consolidated budget revenues, bln. & 0.01874 \\
\hline Income of the population, billion UAH & 0.01871 \\
\hline Total volume of trades for the period, UAH billions. & 0.01738 \\
\hline Capital of banks, billion UAH & 0.0184 \\
\hline The number of registered unemployed, million people & 0.01553 \\
\hline Loans granted, UAH billions & 0.01573 \\
\hline Loans to business entities, UAH billions. & 0.01792 \\
\hline Loans, UAH billions & 0.01573 \\
\hline M0 billion UAH & 0.01771 \\
\hline M1 billion UAH & 0.01817 \\
\hline M2 billion UAH & 0.01832 \\
\hline M3 billion UAH & 0.01832 \\
\hline State debt service, UAH billions. & 0.01819 \\
\hline The volume of operations with cerebral palsy, billion UAH. & 0.01521 \\
\hline Volume of trades on the securities market, UAH billions. & 0.01654 \\
\hline Volumes of assets of 5 largest banks, billion UAH. & 0.0182 \\
\hline $\begin{array}{l}\text { Share of long-term loans in the total volume of loans granted } \\
\text { by commercial banks, } \%\end{array}$ & 0.01844 \\
\hline Regulatory capital, billion UAH & 0.01794 \\
\hline The level of foreign debt per one person, USD USA & 0.01858 \\
\hline $\begin{array}{l}\text { The average weighted interest rate on loans in relation to the } \\
\text { consumer price index, } \%\end{array}$ & 0.01699 \\
\hline $\begin{array}{l}\text { The average weighted interest rate on loans granted by deposit-tak- } \\
\text { ing corporations (except the National Bank) in the national cur- } \\
\text { rency, in relation to the consumer price index, percentage points }\end{array}$ & 0.0164 \\
\hline $\begin{array}{l}\text { The average interest rate on commercial banks' loans in relation } \\
\text { to inflation, } \%\end{array}$ & 0.01699 \\
\hline The average monthly nominal value, UAH & 0.01867 \\
\hline The ratio of liquid assets to short-term liabilities, percentages & 0.01587 \\
\hline $\begin{array}{l}\text { The share of foreign bank capital in the total amount of bank } \\
\text { capital, } \%\end{array}$ & 0.01769 \\
\hline $\begin{array}{l}\text { Share of insurance premiums of the three largest insurance } \\
\text { companies in the total amount of insurance premium receipts } \\
\text { (except life insurance), percent }\end{array}$ & 0.01715 \\
\hline $\begin{array}{l}\text { The share of the total authorized capital of insurance compa- } \\
\text { nies belonging to non-residents in their total volume, } \%\end{array}$ & 0.01715 \\
\hline \multicolumn{2}{|l|}{ Stimulants } \\
\hline Gross international reserves of Ukraine, months of import & 0.0152 \\
\hline Relative value of reserves to external debt, $\%$ & 0.0171 \\
\hline $\begin{array}{l}\text { Deficit / surplus of budget and extrabudgetary funds of the } \\
\text { state-owned sector, percentage of GDP }\end{array}$ & 0.0172 \\
\hline Consumer price index, $\%$ & 0.0166 \\
\hline Inflation rate (as of December of the previous year), $\%$ & 0.0166 \\
\hline $\begin{array}{l}\text { The ratio of bank loans and deposits in foreign currency, per- } \\
\text { centages }\end{array}$ & 0.0169 \\
\hline $\begin{array}{l}\text { The share of loans in foreign currency in the total amount of } \\
\text { loans granted, percentages }\end{array}$ & 0.0160 \\
\hline Share of consumer loans in the general structure of loans, $\%$ & 0.0162 \\
\hline
\end{tabular}


Table 4 (cont.). The weights for calculating the level of financial security in Ukraine

\begin{tabular}{|l|c|}
\hline \multicolumn{1}{|c|}{ Indicators } & \multicolumn{1}{|c|}{ Value of weight coefficients } \\
\hline \multicolumn{1}{|c|}{ Stimulants } \\
\hline \multicolumn{1}{|c|}{ 1 } \\
\hline $\begin{array}{l}\text { Share of consumer loans granted to households in the general } \\
\text { structure of loans granted to residents }\end{array}$ \\
\hline $\begin{array}{l}\text { Aggregated indicator of violation of financial discipline in } \\
\text { transactions with public funds and property }\end{array}$ \\
\hline \multicolumn{1}{|c|}{ Catalysts } \\
\hline Profitability of banks' assets, $\%$ & 0.0163 \\
\hline Return on capital of banks, $\%$ & 0.3271 \\
\hline Growth of real disposable income of physical persons, $\%$ & 0.0156 \\
\hline Results of activity (profit) of enterprises, UAH billions. & 0.0165 \\
\hline Return on assets of enterprises, $\%$ & 0.0152 \\
\hline Inhibitors & 0.0156 \\
\hline The ratio of long-term (over 1 year) loans and deposits, times & 0.0153 \\
\hline Deposit rates, $\%$ & 0.0152 \\
\hline Rates on loans, $\%$ & 0.0178 \\
\hline Share of public debt securities coverage, $\%$ & 0.0151 \\
\hline
\end{tabular}

Source: Own calculations. 